\title{
Schools as Professional Learning Communities
}

\author{
Markku Antinluoma ${ }^{1}$, Liisa Ilomäki ${ }^{1}$, Pekka Lahti-Nuuttila ${ }^{2} \&$ Auli Toom ${ }^{3}$ \\ ${ }^{1}$ Department of Education, University of Helsinki, Helsinki, Finland \\ ${ }^{2}$ Department of Behavioural Sciences, University of Helsinki, Finland \\ ${ }^{3}$ Centre for University Teaching and Learning (HYPE), Faculty of Educational Sciences, University of Helsinki, \\ Finland \\ Correspondence: Markku Antinluoma, Department of Education, University of Helsinki, Finland.
}

Received: June 12, 2018

doi:10.5539/jel.v7n5p76
Accepted: July 7, $2018 \quad$ Online Published: July 20, 2018

URL: https://doi.org/10.5539/jel.v7n5p76

\begin{abstract}
The main objectives in building professional learning communities are to improve teachers' professionalism and well-being, and create positive impacts on student learning. It is a question of changing the school culture. The main objective of this quantitative study was to investigate the maturity level of thirteen Finnish schools as professional learning communities from the perspectives of school culture, leadership, teaching, and professional development. The participants' perceptions indicated a culture of collegiality, trust and commitment as common strengths at all schools. The school cultures supported professional collaboration, and the teachers had the knowledge, skills and dispositions to engage in professional collaboration. The challenges were related to structural conditions, especially the lack of collaboration time. Three school profiles were identified in the cluster analysis from the viewpoint of maturity as professional learning communities. Statistically significant differences between the three clusters were found in organizational and operational characteristics.
\end{abstract}

Keywords: professional learning community, distributed leadership, teacher collaboration, school culture

\section{Introduction}

The contemporary global concern for learning outcomes and well-being in schools has led to whole school reforms (Harris, 2011), which involves pressure for better student performance (Daly, 2009). The external pressure for better performance and accountability polices has partly emerged from publication of international comparative performance studies (Harris, 2011). International PISA studies (OECD, 2007; 2012; 2015) have revealed that during the last ten years in Finland, there have been signs of declining learning outcomes in pupils completing their basic education and the proportion of young people with poor basic skills in different cohorts has grown, and attitudes that obstruct learning have become stronger (FMEC, 2015). Regardless of these challenges, Finland has not joined the global education reform movement and has not adopted outcome-based education (Sahlberg, 2011) and has not tried to improve student performance through tighter accountability systems. In Finland, one answer to global and local challenges has been continuous development of the national core curricula (FNBE, 2014). The core curricula for basic education has been traditionally reformed every $10^{\text {th }}$ year (Pietarinen et al., 2017; Pyhältö et al., 2012). The new core curriculum emphasizes the joy of learning, the pupils' active role, positive emotional experiences, collaborative working, interaction, creative activity enhancing learning, transversal (generic) competences and work across school subjects (FMEC, 2015). Additionally, according to the national core curriculum 2014 for basic education some of the key aims are: developing schools as learning communities, distribution of leadership, emphasizing the joy of learning, emphasizing collaborative atmosphere and promoting student autonomy in studying and in school life (FNBE, 2014).

The global educational trends influence Finnish education and there are signs of education policy borrowing both in practice and in curricula. One evidence of this is the adoption of the ideas of the learning community, which is according to studies an effective strategy to improve teaching and learning, and thus provides meaningful working and learning environments for pupils and teachers (DuFour \& Mattos, 2013; Hargreaves \& Fullan, 2012; Owen, 2015; Sigurðardóttir, 2010; Vescio et al., 2008). Additionally, effective professional learning communities operating within innovative contexts increase the well-being of teachers and students (Owen, 2015). The idea of learning organization, later labelled as learning community, has been in Finnish educational 
discourse and practice since the 70's. In this discourse the term work community (MoE, 2001) was used and teachers still use it, beside the term learning community, when referring to the functioning of the school as a whole (Webb et al., 2009).

There has been little quantitative analysis of Finnish schools as professional learning communities and thus this study aims to fill this empirical research gap. Internationally, findings of this study are attracting considerable interest due to the Finnish results in international studies. This study offers a Finnish view to schools as learning communities, where teachers have a high level of independency and university-level education as personal resources and the school is not led by results of intensive testing. The focus of this article is to investigate principals' and teachers' perceptions of their schools' maturity level as professional learning communities from the perspectives of organizational and operational characteristics in order to recognize their own strengths and barriers (maturity), and thus to support their schools' development as professional learning communities.

\subsection{Schools as Professional Learning Communities}

The concept of professional learning community (later referred as $P L C$ ) in education has been modified from the learning organization concept used in the business sector (Senge, 1996; Vescio et al., 2008) and in organizational theory (Leclerc et al., 2012), starting from concepts of collegiality and collaboration that finally developed into PLC (Lomos et al., 2011). Regardless of broad research, there is no universal definition (Sleegers et al., 2013; Stoll et al., 2006; Vescio et al. 2008) of PLC. It has been conceptualized and operationalized differently in different research settings without final agreement on which and how many interrelated characteristics are needed to operationalize and measure PLCs (Lomos, 2017). The conceptual challenge with the PLC is on its multidimensional and multilevel nature (De Neve et al., 2015; Sleegers et al. 2013): studies emphasize the importance of different dimensions differently: same dimension can be treated as a key dimension (Hord, 2004), it is not mentioned (Hord, 1997, 2004) or it is mentioned as supportive condition (Louis \& Kruse, 1995). Due to these challenges PLC is still in a developmental stage of theory building (Stoll et al., 2006; Vescio, Ross, \& Adams, 2008), and it has proved difficult to measure (Lomos, 2017).

The underlying assumption of PLC is that the core mission of formal education is deep learning, not teaching (DuFour, 2004; Hargreaves, 2007) and this shift of focus has profound implications for schools. Out of many different definitions, this study draws on the definition by Stoll et al. (2006, p. 5): "a professional learning community is an inclusive group of people, motivated by a shared learning vision, who support and work with each other, finding ways, inside and outside their immediate community, to enquire on their practice and together learn new and better approaches that will enhance all pupils' learning".

\subsection{Organizational Characteristics of Schools as PLCs}

This study focuses on two aspects of internal characteristics introduced by Williams et al. (2008): a) organizational characteristics: culture, leadership, and capacity-building, and b) operational characteristics: professional development, data collection, and systemic trust. These characteristics have a critical impact on successful implementation of PLC (Williams et al., 2008), are consistent with the chosen definition (Stoll et al., 2006a) and cover components identified by Hord (2009): 1) shared beliefs, values and vision, 2) shared and supportive leadership, 3) structural and relational supportive conditions, 4) collective intentional learning and its application and 5) shared personal practice.

The culture of a school is one of PLC's critical organizational characteristics (Williams et al., 2008) and it may be invisible, conscious or unconscious (Teasley, 2017), positive or negative (Glossary of Education Reform, 2013). School culture describes the character of the school and functions of the organization (Van Houtte, 2005), and it consists of the norms, values and social interaction in the organization. Culture builds a sense of cohesion within schools and provides a sense of identity; it promotes achievement orientation, helps shape standards and patterns of behaviour, creates distinct ways of doing things, and determines direction for future growth (Teasley, 2017, p. 3). Positive school culture is conducive to professional satisfaction, effectiveness, morale, and creates an environment that maximizes student learning and fosters collegiality and collaboration (Glossary of Education Reform, 2013). Creating a positive school culture is critical in implementing PLC, because school culture influences readiness for change and effective schools establish professionally collaborative cultures (Fullan, 2001), which has a positive effect on student learning (Stoll, 2006). Teaching culture is improved when the learning communities increase teachers' collaboration and empowerment, break down walls of isolation, create collective responsibility (DuFour \& Mattos, 2013; Hargreaves \& Fullan, 2012), and secure continuous professional learning (Vescio et al., 2008).

Leadership is the second important organizational characteristic of a school (Williams et al., 2008). Stoll (2006) argues that the nature and quality of leadership has a significant influence on the nature of the school culture. 
Without a strong principal support, regardless of the leadership style, PLCs will not sustain within a school (Bryk et al., 1999). Principals play a key role in nurturing climate that supports innovative professional activity and to be successful, they must provide time and resources (Bryk et al., 1999). Time is a crucial factor that represents the greatest challenge for the implementation of PLCs (Hord \& Sommers, 2008; Leclerc et al., 2012). Morrissey (2000) found that if principals do not identify a shared focus, they are not able to guide their staff in developing and articulating a collective vision for their students or their school. Additionally, leadership is a dynamic process involving many individuals (Cibulka, Coursey, \& Nakayama, 2000) and distribution of leadership is one of the key factors in implementing a PLC (DuFour \& Mattos, 2013; Harris, 2004; 2011; Leclerc et al., 2012; 2000; Sleegers et al., 2013). Studies indicate that distributed leadership, organizational development and student outcomes are interconnected (Heck \& Hallinger, 2009; Leithwood \& Mascall, 2008). Distribution of leadership has positive effects on teachers' professional development (Kennedy et al. 2011), student engagement, realization of changes and commitment to shared goals (Leithwood \& Janzi, 2000). Previously, instructional leadership was assumed to be solely the responsibility of the principal (Hansen \& Lárusdóttir, 2015), but recent research acknowledges that it should be shared by principals and other professional staff (Robinson et al., 2008) and that this form of distributed instructional leadership is more effective (Bush and Glover, 2014). The success of distributed leadership depends on the growth state of the organization, its readiness to change, its culture and developmental needs, the pattern of distribution and its purpose (Harris, 2008). Distributed leadership requires strong and supportive formal leadership in defining the autonomy and authority of informal leaders; in securing PD resources; in modelling the vision and focus; and in creating trust environments (Harris, 2011). A distributed approach to leadership carries various limitations. First, leadership models are partial (Bush, 2011; Gronn, 2008). Second, distribution of leadership is limited because formal leaders are responsible for decisions and are accountable for the school's performance. Third, distributing leadership does not seem to result in less demand for formal leadership, because formal leaders have to "coordinate, build capacities, and monitor the leadership work of those others" (Leithwood et al., 2007, p. 63). Fourth, Tian et al. (2015) argue that the main unsolved challenge has been the lack of a universal definition of distributed leadership. Fifth, it may be questionable to connect distributed leadership directly to learning outcomes.

The third organizational characteristic, capacity-building, is essential to implementation and the sustainability of PLCs (Hargreaves \& Fink, 2006). School capacity consists of three mutually influencing and interdependent categories: individual (knowledge, skills, and dispositions), collective (quality of collaboration among members of the teaching staff), and organizational factors (structural factors) (Mitchell \& Sackney, 2000). The core purpose of PLC is to enhance teachers' effectiveness as professionals (Stoll et al., 2006) and to improve student learning (DuFour, 2004.; The focus must be on changing and improving instructional practice (Hipp et al., 2008; Vescio et al., 2008). Several studies have supported the idea that participation in a learning community leads to changes in teaching practice (Little 2012; Vescio et al., 2008) and teachers, who are offered rich learning opportunities, teach in more ambitious and effective ways (Little, 2012). It has been argued that collaboration outside classrooms is important for school improvement, teachers' professional development, and student learning (DuFour, 2004; Sleegers et al., 2013). Fullan and Hargreaves (2012, p. 2) have introduced the idea of professional capital, which has three components: human, social, and decisional. Human and individual capital must be complemented and raised by social capital. They (Fullan \& Hargreaves, 2012) argue that social capital is more important than individual human capital because it generates human capital faster. Social capital supports leaders to strengthen their school communities, develop greater trust, and build more effective professional collaboration.

\subsection{Operational Characteristics of Schools as PLCS}

The operational characteristics of a PLC are composed of three diverse important factors connected to the implementation of PLC: professional development (PD), use of data, and system-wide trust (Williams et al., 2008). Continuous and ongoing professional development can be arranged in diverse ways (Kennedy, 2014), but learning in PLCs, beside the forms of individual PD activities, is embedded in the daily collaborative work as teachers accumulate and circulate knowledge, implement it, and, from the experience, gain yet more knowledge (Hargreaves \& Fullan, 2012; Richmond \& Manokore, 2011; Sigurðardóttir, 2010). PD in PLCs represents a fundamental shift away from the traditional model of professional development (Vescio et al., 2008), and teachers identify and value collegiality as crucial for their own professional growth (Richmond \& Mankore, 2011). This embedded PD can take diverse forms: co-teaching; lesson reflection; mentoring and tutoring practices; participation in instructional teams and networks; and involvement in development or improvement processes, such as designing and implementing curriculum or schools' annual plans (Ilomäki, Lakkala, Toom, \& 
Muukkonen, 2017; Lakkala \& Ilomäki, 2015).

A second operational characteristic at the school level is the collection and use of data. Muñoz \& Branham (2016, p. 40) found a clear connection between "proper implementation of PLCs and the use of quality and timely data that allowed regular monitoring of student learning by transforming academic data into actionable information". Implementation of results-oriented PLCs will be successful if it is coupled with effective PD and actionable data (Muñoz \& Branham, 2016). Actionable data can be described as useful and relevant information for staff (DuFour, 2004), and it emphasizes formative assessment of student learning (Guskey, 2007). Hargreaves (2007) argues that by concentrating first on learning, before achievement and testing, PLCs reach better learning results. To improve the quality of learning, PLCs ground their actions on diverse inside and outside evidence, on multiple sources of data and new cultures of evidence-informed inquiry (Hargreaves, 2007). Key issues in the use of data are the selection of relevant data, how it informs decision making (Williams, 2008) and how the data are processed by the school community. In PLCs all information and data are interpreted communally distributing them among themselves (Stoll et al., 2006, p. 227).

Trust, the third operational characteristic, grounds a powerful social resource for supporting the collaboration, reflective dialogue, and deprivatization characteristics of a professional community (Bryk et al., 1999). Hargreaves (2007, p. 187) describes trust as the backbone of a strong and sustaining PLC: "colleagues value each other personally and professionally, are committed to their students, are willing to discuss and disagree about evidence and data that can inform them about how to improve their practices in ways that benefit their students, and are willing to challenge one another's practice in doing so". Tschannen-Moran (2004) argue that creating trust among teachers may be more significant in stimulating changes in practice than does having a trusting relationship with the principal. Similarly, Wahlstrom and Louis (2008) found that the effect of teachers' trust in the principal becomes less important when shared leadership and professional community are present. Regardless, the trust on leader is important in creating other forms of trust (Tschannen-Moran, 2004).

Reculturing schools towards being PLCs is a continuous improvement process, a journey, that starts from the maturity level of an individual school (Bolam et al. 2005; Muñoz \& Branham, 2016), with possible drawbacks, rather than the end result of something (Hipp \& Huffman, 2003; Hipp et al., 2008). PLCs are fluid entities (Bolam et al. 2005), and it is not possible to say exactly when a school begins to develop towards being a PLC and when this development has effects on learning outcomes (Sigurðardóttir, 2010). In addition, some schools move along in their efforts at a steady pace, while others stall and proceed without reculturing (Fullan, 2000).

\section{Aims of the Study}

The aim of this study was to explore the perceptions of comprehensive school principals and teachers concerning their schools' maturity level of the organizational and operational characteristics. The aim was also to identify school clusters according to the development level (maturity) of the organizational and operational characteristics. Further, the aim was to investigate the interrelatedness of the characteristics of a PLC.

The specific research questions were as follows:

(1) What are the main common organizational and operational strengths and challenges of the participating schools as PLCs?

(2) Which schools' profiles can be distinguished based on the level of the organizational and operational characteristics as PLCs (as perceived by the principals and teachers)?

\section{Methods}

\subsection{Context and Participants}

Finland has 9 years basic education (six primary, three lower secondary and an optional $10^{\text {th }}$ year), three years upper secondary education and four years higher education. Pre-primary education is provided in the year preceding the start of compulsory education. Nearly all 6-year-olds are enrolled in voluntary pre-primary education. Children begin at primary school that year they attain seven years. Municipalities and the State are responsible for organizing publically funded pre-primary and basic education. Basic education can be provided in separate primary and secondary schools or in comprehensive schools, were primary school and lower secondary school are combined in one unit. Municipalities are responsible for teaching, the effectiveness and the quality of the education. Municipalities determine the level of schools' autonomy. There are only a few private schools, and even they follow the national curriculum and their main funding comes from the municipalities. Teaching is a popular profession and the admission rate to class teacher education was $11 \%$ in 2016 . Nearly all principals, lecturers and class teachers in basic education were fully qualified. Finnish specifics in basic education are the following: no inspections, no national exams, no teacher evaluation, teachers feel valued by 
society, short school days, low amount of homework and increased amount of lessons in art, music and physical education (FNBE, 2016). School leadership structures are low: principal and one or more assistant or vice principals depending on school size. Principals' teaching responsibilities vary from 2-13 hours a week depending on number of classes in school. School heads in smaller schools may teach almost as many hours as teachers.

The respondents (principals and teachers) in this study were from primary, lower secondary and comprehensive schools (school types), located in different regions of Finland. The schools had a total of approximately 3,660 students and 320 teachers. In total, 227 teachers and principals from 13 schools completed the questionnaire. The answers of 15 respondents were deleted because the response rate in the school was lower than $40 \%$, and thus these schools were left out of the analysis. After this, the average response rate of the schools was $72 \%(41 \%-$ $100 \%$ ) (see Table 1). The final sample of participants consisted of 8 principals, 11 assistant principals, 122 class teachers, 78 subject teachers, all of which made a total of 212 (because seven of the assistant principals also worked as teachers). In addition, 127 of the participants worked in primary schools, 69 in lower secondary schools and 16 in comprehensive schools. Table 1 describes the number of school types and respondents.

Table 1. School types and respondents

\begin{tabular}{lll}
\hline School type & $N$ & Respondents \\
\hline Primary schools (classes 0-6) & 8 & 127 \\
Lower secondary schools (classes 7-9) & 4 & 69 \\
Comprehensive schools (classes 1-9) & 1 & 16 \\
\hline Total & 13 & 212 \\
\hline
\end{tabular}

Note. * There are differences between municipalities concerning pre-school (0 class) arrangements. Depending on municipal decisions, pre-school administration can be arranged by education or social administration offices.

In this study $84 \%(\mathrm{~N}=177)$ of the respondents were female and $16 \%(\mathrm{~N}=35)$ male. In $2016,77 \%$ of Finnish basic education teachers were women (FNBE, 2016). Women were slightly overrepresented in the sample used for this study. In total, $38 \%$ of the participants were under 40 years of age, $36 \%$ were aged between 40 and 49 years, and $26 \%$ were older than 50 years of age. In 2016, 39\% of Finnish teachers and $60 \%$ of principals were over fifty. The proportion of teachers over fifty was smallest in basic education (FNBE, 2016). The respondents of the study were experienced in education, with $63 \%$ having more than 10 years of experience and $15 \%$ having more than 20 years of experience. $18 \%$ of the participants had 1-5 years of experience. The length of service for $67 \%$ of participants was less than 10 years and $66 \%$ had participated annually in professional development. In 2016, $80 \%$ of teachers participated in in-service-training or mobility programmes (FNBE, 2016). $32 \%$ of the participants were leadership team members and $56 \%$ had been leadership team members, $80 \%$ had been a leadership team member for less than five years and $32 \%$ had participated in leadership training.

The participation in this research was voluntary for principals and teachers. Municipalities granted the research permissions, and principals decided on whether their schools would participate in the study. Finally, teachers decided on their involvement and gave personal permissions for their responses to be used in this research. The research has been conducted according to the guidelines for the responsible conduct of research (Finnish Advisory Board on Research Integrity, 2012). Schools and individuals were coded, and responses were given anonymously. This approach enabled teachers and principals to evaluate their schools frankly and critically.

\subsection{Measures and Data Collection}

The data was collected in 2011-2014 during a PLC training program for school leadership teams (schools N=13) with the use of the "School-Level Readiness Instrument" (SLRI; Williams et al., 2008). In this study readiness is interpreted as maturity. This training was organized collaboratively by three municipal education offices and the Continuing Education Centre of the University of Helsinki. The aim of the data collection was to design schools' PLC development plans and to improve schools' capacity as PLCs. This data was also used in this study.

The School-Level Readiness Instrument (SLRI; Williams et al., 2008) was found to be an appropriate instrument for the Finnish context. This Canadian instrument was chosen because schools in both countries are being developed as PLCs. The countries have a similar general standard of living, a well-developed public education system, and top results in international school achievement tests (OECD, 2007; The Conference Board of Canada, 2014) and the countries are comparable on several substantial levels (Jahnukainen, 2011).

The SLRI was constructed around four attributes based on the critical organizational and operational (4) characteristics of the PLC: 1) culture, 2) leadership, 3) teaching (capacity-building), and 4) PD (professional 
development, use of data and trust). Twenty statements describe these attributes and measure the schools' maturity as PLC. Each of the attributes included five declarative statements addressing the theme (see Appendix A). Each statement dealt with one to four questionnaire items (62 in total) answered on a Likert scale 1-5. Responses 1, 3 and 5 on the scale had written descriptors to facilitate choice, and responses 2 and 4 were left without descriptors (example: 1: This school has a vision, but it is not used to guide decision making, 2: no descriptor, 3: This school has a vision that occasionally guides decision making, 4: no descriptor and 5: This school has a vision that directly guides important decisions). The descriptors for responses coded as 1 described conditions that were more closely associated with a traditional bureaucratic school, and the descriptors for responses coded as 5 described those more characteristic of PLCs (Williams et al., 2008).

For this study, the instrument was translated into Finnish and adjusted to the Finnish context. It was piloted with teachers at one primary school, reviewed by a primary school teacher and an upper secondary school principal. The instrument was revised further according to the feedback received. In total, 19 items were adjusted (13) or deleted (6). The deleted items concerned hiring a new principal, assignments for non-teaching staff, professional development of paraprofessionals, and disciplinary actions, which are not organized the same way in Finland and Canada. Changes to the items were minor. The attributes of culture needed fewer changes, which suggest that the instrument is appropriate for usage in Finland, despite the national differences in teacher education, administration and management. After revisions, the questionnaire included 20 statements and 57 items. The scales and the items are presented in Appendix A.

\subsection{Data Analysis}

The quantitative data was processed using SPSS software. There were 1\% (124 of 12084) missing values and EM Algorithm imputation was used to impute missing data based on age, gender and items. The following analyses were conducted: descriptive statistics, reliability of the measures, a one-way analysis of variance (ANOVA) between age groups, gender, position, school types, schools, clusters, Tukey's post-hoc test to analyse the differences between the schools, K-means cluster analysis to identify the school clusters, and Tukey's post hoc multiple comparison test to analyse the differences between clusters.

The coefficient of internal consistency reliability of the measures was analysed (Table 2). The culture subscale consisted of 15 items; the leadership subscale consisted of 15 items; the teaching subscale consisted of 13 items; and the professional development subscale consisted of 14 items. The analysis indicated a high level of internal consistency in the measures, and the four measures were found to be highly reliable.

Table 2. Means, standard deviations and alphas among the PLC scales (and items) in the survey

\begin{tabular}{lllll}
\hline Characteristics & $N$ & $M$ & $S D$ & $\alpha$ \\
\hline Culture (15 items) & 212 & 3.6 & 0.53 & 0.84 \\
Leadership (15 items) & 212 & 3.4 & 0.60 & 0.86 \\
Teaching (13 items) & 212 & 3.6 & 0.52 & 0.82 \\
Professional development (14 items) & 212 & 3.5 & 0.63 & 0.86 \\
\hline
\end{tabular}

Differences depending on age group, gender or position were analysed by using one-way ANOVA. The analysis indicated that there were no statistically significant differences between age groups, genders or positions.

\section{Results}

\subsection{Reported Strengths and Development Challenges of the Schools}

Responses to 20 statements (57 items) indicated some common strengths (4-5 on the Likert scale) and barriers (1-2 in the Likert scale) in the participating schools. Responses to culture statements indicated two common strengths in the participating schools. The schools received high scores in collegiality, trust, and commitment $(\mathrm{M}=4.3)$ and in professional collaboration $(\mathrm{M}=4.1)$. Within the culture statements, $87 \%(\mathrm{~N}=185,4-5$ in the Likert scale) of teachers and principals reported that teachers were treated as professionals, $81 \%$ reported they were receptive to the presence of other professionals in their classrooms, $78 \%(\mathrm{~N}=165)$ reported that there was a high degree of trust among teachers to support the sharing of instructional practices, and $76 \%(\mathrm{~N}=160)$ reported that their dialogue often dealt with student learning. Responses to leadership statements indicated one common strength in the participating schools: $76 \%(\mathrm{~N}=160,4-5$ in the Likert scale) of respondents indicated that most teachers had expertise in collaborative skills such as conflict resolution, consensus building, problem solving, and team building. Responses to teaching statements indicated three strengths in the participating schools. First, teachers were encouraged to use professional collaboration to learn effective instructional and assessment 
practices $(\mathrm{M}=4.0)$. Second, instructional practices met the needs of students of all ability levels $(\mathrm{M}=4.1)$, and third, interventions were provided to students who require additional support $(\mathrm{M}=4.3) .89 \%$ of the respondents indicated that their teaching approach is modelled on the best teachers they had had at the school, combined with their personal reflection and collaboration with colleagues. In total, $80 \%(\mathrm{~N}=169)$ indicated that additional support for students functioned well. Altogether $57 \%(\mathrm{~N}=120)$ answered that most teachers at their school use a variety of ongoing approaches to assess student learning. Responses to professional development statements indicated one strength in the participating schools: professional growth was a multi-faceted, systemic and on-going component of school improvement efforts $(\mathrm{M}=4.1)$. Within professional development statements, $80 \%$ $(\mathrm{N}=170,4-5$ in the Likert scale) reported that they defined professional collaboration as working with colleagues on tasks that improve student learning. $77 \%(\mathrm{~N}=164)$ of respondents reported that most teachers at their school had the skills to collaborate professionally with their colleagues, and $75 \%(\mathrm{~N}=158)$ that their professional development was an on-going collaborative learning process that extends beyond professional development sessions.

The analysis indicated the following barriers: $55 \%(\mathrm{~N}=116,1-2$ in the Likert scale) answered that some teachers were assigned meeting times during the regular school day to discuss student learning. 44\% $(\mathrm{N}=93)$ reported that assessment was sometimes shared only among a few teachers, and 36\% ( $\mathrm{N}=76)$ answered that teacher discussions during breaks and preparation time were only occasionally centred on student learning. $31 \%(\mathrm{~N}=65)$ reported that teachers occasionally had time to discuss best planning practices or collaborate on lesson planning. $25 \%(\mathrm{~N}=53)$ reported that the daily schedule limited teacher collaboration and the physical layout of school building limited teacher collaboration somewhat. $25 \%(\mathrm{~N}=53)$ reported that district data were sometimes used to make instructional decisions.

\subsection{Differences Between School Types and Schools}

The differences between the school types (primary, lower secondary and comprehensive schools) and the schools in their maturity to operate as PLCs were explored from the perspective of four characteristics (see Appendix B). Differences between primary, lower secondary and comprehensive schools in culture, leadership, teaching and professional development were analysed by using one-way ANOVA. There were statistically significant differences between school types only in culture characteristic F $(2,209)=5.58, \mathrm{p}=.004)$. A Tukey's post-hoc test revealed a statistically significant difference in culture between primary and comprehensive schools $(\mathrm{p}=.004)$ and between lower secondary schools and comprehensive schools $(\mathrm{p}=.045)$, but because of the low number of participating schools, further conclusions cannot be drawn.

In the next phase, the significance of differences in means between the schools in all four characteristics of PLCs were analysed by using one-way ANOVA (Table 3). The analysis indicated statistically significant differences between the schools in the means of all four dimensions.

Table 3. Differences between schools in characteristics

\begin{tabular}{llllll}
\hline Characteristics & $S S$ & $d f$ & $M S$ & $F$ & $P$ \\
\hline Culture & 16.02 & 12 & 1.34 & 6.22 & $\mathrm{P}<0.001$ \\
Leadership & 18.38 & 12 & 1.53 & 5.52 & $\mathrm{P}<0.001$ \\
Teaching & 10.93 & 12 & 0.91 & 3.89 & $\mathrm{P}<0.001$ \\
Professional development & 21.65 & 12 & 1.80 & 5.75 & $\mathrm{P}<0.001$ \\
\hline
\end{tabular}

\subsection{Schools' Maturity Profiles as PLCs}

Schools were placed into one of three clusters by using the K-means cluster analysis. The Tukey's test indicated that there are statistically significant differences at the .05 significance level between the three clusters in all four characteristics. However, it is important to acknowledge that participants' perceptions revealed four development areas common to all clusters: the impact that structural factors have on professional collaboration had been addressed ( $M=2.7-3.3)$; decisions were based on careful analysis of school-based data on student performance $(M=2.7-3.3)$; effective lesson planning was vital for improving student achievement $(M=2.9-3.4)$; and professional development for teachers was organized according to a comprehensive plan focusing on the school's vision ( $M=2.6-3.3)$. School cluster centres in culture, leadership, teaching and professional development are shown in Figure 1. The results indicated that within school clusters, there existed a pattern in the maturity level: perceptions about the four characteristics were at the same level within the clusters. Thus, it confirmed that there was an interrelatedness between the characteristics of a PLC. 


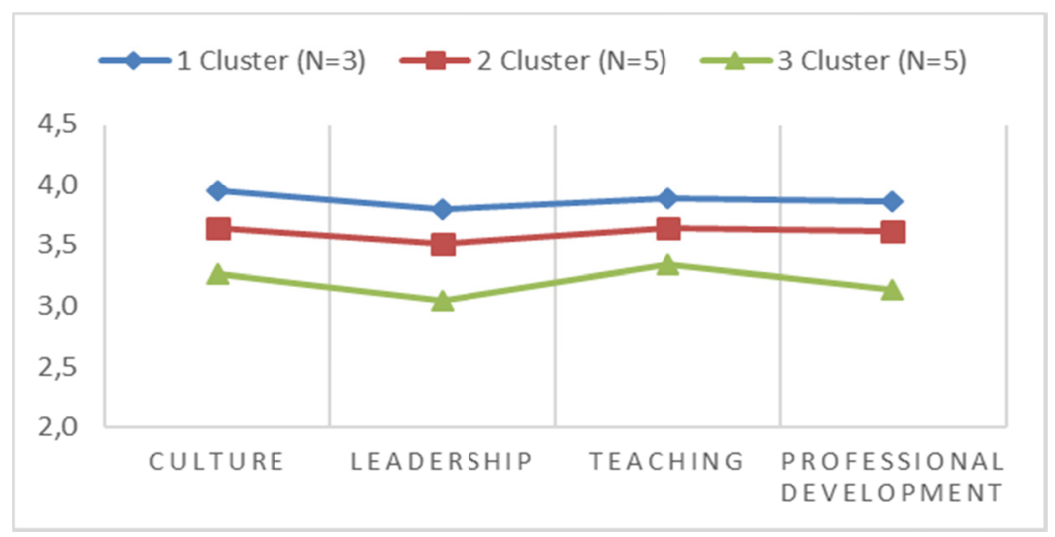

Figure 1. School cluster centers

In the following, the maturity of the school clusters as PLCs is described according to strengths $(M>4.0)$ and barriers $(\mathrm{M}<3.5)$.

Cluster 1. According to teachers' and principals' perceptions, these schools had strong cultures of collegiality, trust and commitment $(M=4.6)$, and culture which supported professional collaboration $(M=4.3)$. Responses to teaching statements indicated four strengths: teachers were encouraged to use professional collaboration to learn effective instructional and assessment practices $(\mathrm{M}=4.3)$, instructional practices at this school met the needs of students of all ability levels $(\mathrm{M}=4.3)$, interventions were provided for students who require additional support $(\mathrm{M}=4.3)$, and assessment was a key component of instructional practices and contributed to student learning $(\mathrm{M}=4.0)$. Within professional growth and development statements, two strengths were reported: professional growth was a multi-faceted, systemic and on-going component of school improvement efforts $(\mathrm{M}=4.2)$, and teachers had the knowledge, skills, and dispositions to engage in professional collaboration $(\mathrm{M}=4.3)$. These schools had two strengths in leadership: building leadership capacity among both teachers and support staff reinforced learning for both teachers and students $(\mathrm{M}=4.0)$, and the sharing of leadership strengthened the leadership capacity $(\mathrm{M}=4.3)$. Participants' perceptions indicated that cluster 1 schools had the same barriers as schools in other clusters, and no challenges were specific to cluster 1. Summing up the results, these schools had the readiness to operate as PLCs.

Cluster 2. Schools in cluster 2 had a culture of collegiality, trust, and commitment $(\mathrm{M}=4.3)$ and the culture supported professional collaboration $(\mathrm{M}=4.2)$. The main differences compared to cluster 1 schools were that the sharing of leadership strengthened the leadership capacity less $(M=3.7)$, and teachers participated less in decisions regarding resource allocation $(\mathrm{M}=3.3)$. The respondents also reported that they had less time to collaborate with their colleagues regarding student learning $(M=2.9)$, they recognized less the importance of effective communication $(\mathrm{M}=3.3)$, and assessment was a key component of instructional practices and contributed to student learning $(\mathrm{M}=3.5)$.

Cluster 3. Based on the Tukey's post hoc test, the maturity level as a PLC in schools of cluster $3(\mathrm{~N}=5)$ differed statistically significantly in all four characteristics from schools in clusters $1(\mathrm{~N}=3)$ and $2(\mathrm{~N}=5)$. These schools face several barriers in implementing the ideas of a PLC. Within cultural statements, high scores in collegiality, trust, and commitment, and culture supporting professional collaboration $(\mathrm{M}=3.9)$ were reported. As a strength in teaching, respondents reported that interventions were provided to students who required additional support $(\mathrm{M}=4.1)$. The main differences in relation to other school clusters were in leadership. Results indicated that these schools had visions that occasionally guided decision making $(\mathrm{M}=2.8)$, and leadership was somewhat grounded in effective organizational practices $(\mathrm{M}=2.8)$; they faced more leadership challenges than other participating schools in decision-making regarding resource allocation $(\mathrm{M}=2.9)$, in databased leadership $(\mathrm{M}=2.7)$, and in building leadership capacity among both teachers and support staff $(\mathrm{M}=3.3)$. Additionally, these schools met structural barriers in professional collaboration $(\mathrm{M}=2.7)$, and teachers experienced barriers in organizing time to collaborate with their colleagues regarding student learning $(\mathrm{M}=2.8)$. The respondents reported that effective lesson planning was less vital for improving student achievement $(\mathrm{M}=2.9)$ than at other schools: occasionally they had assigned time to discuss the best planning practices or collaborate on lesson planning. 


\section{Conclusions and Discussion}

The aim of the study was to explore the main common strengths and barriers of the participating schools as PLCs, as perceived and evaluated by teachers. Additionally, the aim was to investigate the maturity of the schools as PLCs. The study has shown that all the participating schools have as strengths a culture of collegiality, trust, commitment, and professional collaboration. Furthermore, teachers are receptive to the presence of other professionals in their classrooms, and there is trust among teachers to support the sharing of instructional practices. Most teachers have expertise in collaborative skills, and they are encouraged to collaborate professionally. Instructional practices meet the needs of students of all ability levels, and interventions are provided for students who require additional support. Teachers at all schools reported that the daily teaching schedules and the school buildings limit teacher collaboration, it is challenging to organize meeting times, and to have time to discuss planning practices or collaborate. Perceptions indicated that the district data are not utilized regularly to make instructional decisions and the assessment is mostly an individual task.

Comparison with the Canadian study (Williams et al., 2012) revealed some similarities in the perceptions of Canadian and Finnish teachers and principals. The reported common strengths were the culture of collegiality, trust, commitment and professional collaboration; teachers' knowledge, skills, and dispositions to engage in professional collaboration; encouragement of professional collaboration to learn effective instructional and interventions provided to students who require additional support. Similarly, to this study, according to the Canadian study the daily schedule limits common teaching assignments and teacher's collaboration. Similar results are described by Jensen, Sonneman et al. (2016). They state that teachers should have reserved time for professional development, but they also remind that securing time for PD hasn't improved student outcomes. They argue that the reason for this failure is that PD is effective only when it becomes a part of daily work.

Additionally, the study aimed to identify the maturity profiles school clusters are comprised of. The maturity level of schools as PLCs was studied by clustering the schools into three clusters. Statistically significant differences were found between the three clusters in culture, leadership, teaching and professional development: the perceptions of school cluster 1 and 2 differed from school cluster 3 . School clusters 1 and 2 differed in leadership and culture. Cluster profiles followed the same maturity order in all characteristics. Based on the results, there was an interrelatedness between the maturity level of the culture, leadership, teaching and professional development. Leaders of the developer schools had succeeded in sharing the leadership and creating collaborative cultures, which supported teaching and professional development. According to previous studies (Bolam et al., 2005; Leclerc et al., 2012; Stoll et al., 2006), certain supportive conditions and circumstances promote schools' progression as PLCs. Summing up the results, it can be concluded that the participating schools had the basic conditions and circumstances but most them have to overcome many barriers to progress as PLCs.

\subsection{Implications for School Development}

Based on the results, we may conclude that the participating schools have cultures of collaboration and trust. System elements make it challenging to find time for discussions about learning, instruction and collaborative evaluation practices. Studies of PLCs have confirmed time as one crucial supportive condition in implementing PLCs (Hord \& Sommers, 2008; Leclerc et al., 2012). To develop schools as PLCs, system elements should be changed. Schools need, within the current framework, to develop and experiment with different ways of organizing daily schedules and teachers' work. In January 2018 The Finnish Trade Union of Education signed an agreement about the possibility to experiment with teacher's working hours. According to this experiment teacher's salaries would be based on actual working hours, not only on lessons and some hours collaboration time. The purpose of this experiment is to secure working time for collaboration, planning and evaluation. In Finland, promising ideas about co-teaching (Leana, 2011) and team teaching are spreading, and many schools are implementing these practices to reduce isolation, and to increase collaboration and competency development. Perceptions also reveal that municipal in-service training and teachers' professional development should be better connected with schools' improvement plans. Participants' perceptions indicated that in eight of the 13 schools, the leadership characteristic was evaluated at a lower level than the other three characteristics. Some of this can be explained by the cultural context: leadership items concerning decisions based on internal, municipal and national data on student performance, may appear difficult to respond to for Finnish teachers. In Finland, there are no standardized exams. The national data are collected with national sample-based tests of learning outcomes and the results of individual schools are not published. Most decisions about assessment and the use of data are made at the municipal and school levels. It has been expressed that data-informed leadership should be practiced more with available data, but not by increasing or standardizing testing. The results indicate that the higher the readiness a school has as a PLC, the more balanced are the different characteristics of PLCs that have 
been developed. Differences between schools and clusters revealed the importance of supporting schools at different readiness levels to secure their further development and prevent negative differentiation. In applying learning community strategy, it may lose its true meaning: (a) what it is, (b) how to implement it, and (c) what kind of results are being achieved (Muñoz and Branham, 2016).

In the Finnish context, the development themes are similar to 30 years ago: operative culture, structures, learning community, working time models, professional development, and leadership (FMEC, 2015), although the understanding of these factors has changed through research and practices, and there have been major changes, for example, in teachers' and principals' roles and in overall collaboration. Nonetheless, these similar themes are signs of unsolved problems, such as those concerning structures for organizing teachers' work and collaboration, as well as developing schools as communities.

The theory of PLC provides one framework for school development, and the PLC instrument could be used to investigate schools. However, because the educational systems are different between countries, the ideas, like PLC, should be nationally adjusted and critically implemented. Webb et al. (2009) noted that the particular cultural context of each country had a profound impact on the education climate and therefore on the nature and potential of the project schools as PLCs. This concerned particularly global pressures for accountability and performativity (Webb et al., 2009).

\section{Methodological Reflection}

There was a need for a diagnostic instrument that could identify a school's development phase as a PLC for internal development purposes and especially from the viewpoint of the teachers. The school-level readiness instrument was designed originally to find the barriers that schools face when they implement the ideas of PLCs (Williams et al. 2012). This study indicated that the instrument's statements concerning the characteristics of PLCs are general enough, with some national adjustments, and thus the instrument could be employed as a self-evaluation tool in the Finnish context in order to reveal challenges and strengths, and as well to compare schools with each other regarding their readiness level. Instruments having 50 or more statements are hard to respond to. The challenge is how to measure a multidimensional and multilevel concept of PLC efficiently without losing relevant data: PLC can't be compressed into only a few attributes and there is no agreement on which attributes are relevant. Designing a Likert scale of PLC attributes has proved to be difficult because PLCs are fluid entities: the challenge is how to design valid descriptors and explain the interconnectedness of dimensions? We agree with Stoll et al. (2007) that the value of these kinds of instruments lies in their potential to serve as a framework, informing and engaging stakeholders in conversations around teaching and learning. In the Finnish context, the instrument should be developed further to measure the learning communities in which students' roles, networks and partnerships are taken into account. The instrument excludes the development and spreading of co-teaching practices, when two teachers or a team collaboratively plan, innovate, teach and evaluate both learning and teaching. These practices occur both inside and outside classrooms and are the basis for profound forms of professional development. In designing instruments, the existence of different leadership and professional development models should be taken into consideration. If this is not done, the instrument simplifies complex phenomena and fails to grasp the reality.

Several limitations of this study need to be acknowledged. A larger number of schools from a larger number of municipalities would have been helpful to analyse school levels and municipal level differences. The use of the instrument revealed some need for improvements in statement and item levels. The instrument was designed specifically for teaching staff, but there is also a need to investigate the perceptions of other staff members who play an important role in promoting learning (Stoll et al., 2007) and participate in formal and informal leadership. Research that combines qualitative data with case studies on successful PLCs and successful progressions connected to improved learning outcomes is necessary, to extend our knowledge of PLCs, as Hord et al. (1999) have suggested. More research is also needed to understand better the concept of PLC, and the interrelatedness of dimensions and students' roles. Further long-term follow-up studies should be done to investigate the development of schools as PLCs.

\section{Acknowledgements}

The authors would like to thank the Centre for Continuing Education, at the University of Helsinki, for the possibility to collect data during the training process, and PhD Minna Lakkala, professor Hanni Muukkonen, and professor emeritus Kauko Hämäläinen, for many useful comments and improvements. 


\section{References}

Bolam, R., McMahon, A., Stoll, L., Thomas, S., Wallace, M., Greenwood, A., \& Smith, M. (2005). Creating and sustaining effective professional learning communities. Bristol: University of Bristol y Department of Education and Skills. Retrieved from https://s3.amazonaws.com/academia.edu.documents/34620163/Creating_and_Sustaining_PLCs_tcm4-6310 34.pdf?AWSAccessKeyId $=$ AKIAIWOWYYGZ2Y53UL3A\&Expires $=1530448681 \&$ Signature $=$ wpqe $\% 2 \mathrm{Bj}$ UzhohZBNmkaDMpYIEa1IY\%3D\&response-content-disposition=inline\%3B\%20filename\%3DCreating_a nd_Sustaining_Effective_Profes.pdf

Bryk, A., Camburn, E., \& Louis, K. S. (1999). Professional community in Chicago elementary schools: Facilitating factors and organizational consequences. Educational administration quarterly, 35(5), 751-781. https:// doi.org/10.1177/0013161X99355004

Bush, T. (2011). Theories of Educational Leadership and management. London: Sage Publications.

Bush, T., \& Glover, D. (2014). School leadership models: What do we know? School Leadership \& Management, 34(5), 553-571.https://doi.org/10.1080/13632434.2014.928680

Cibulka, J., Coursey, S., Nakayama, M., Price, J., \& Stewart, S. (2000). Schools as Learning Organizations: A Review of the Literature. The Creation of High-Performance Schools through Organizational and Individual Learning (Part One of Three). Retrieved from http://www.ericsp.org/digests/ProfDevLitRev.htm

Daly, A. J. (2009). Rigid response in an age of accountability: The potential of leadership and trust. Educational Administration Quarterly, 45(2), 168-216. https://doi.org/ 10.1177/0013161X08330499

De Neve, D., Devos, G., \& Tuytens, M. (2015). The importance of job resources and self-efficacy for beginning teachers' professional learning in differentiated instruction. Teaching and Teacher Education, 47, 30-41. https://doi.org/10.1016/j.tate.2014.12.003

DuFour, R. (2004). What is a "professional learning community"? Educational Leadership, 61(8), 6-11. Retrieved from http://teach.oetc.org/files/archives/ProfLrngCom_0.pdf

DuFour, R., \& Mattos M. (2013). How do principals really improve schools? Educational Leadership, 70(7), 34-40. Retrieved from http://www.tdschools.org/wp-content/uploads/2013/08/PLC_Mattos-DuFour-Article.pdf

Fullan, M. (2000). The three stories of education reform. Phi Delta Kappan, 81(8), 581-584. Retrieved from http://www.pdkintl.org/kappan/kful0004.htm

Fullan, M. (2001). The new meaning of educational change. New York and London: Teachers College Press and Routledge Falmer.

Glossary of Education Reform. (2013). School culture. Retrieved from http://edglossary.org/ school-culture/

Gronn, P. (2008). The future of distributed leadership. Journal of Educational Administration, 46(2), 141-158. https://doi.org/10.1108/09578230810863235

Guskey, T. R. (2007). Using assessments to improve teaching and learning. Ahead of the curve: The power of assessment to transform teaching and learning, 15-29. Bloomington, IN: Solution Tree.

Hansen, B., \& Lárusdóttir, S. H. (2015). Instructional leadership in compulsory schools in Iceland and the role of school principals. Scandinavian Journal of Educational Research, 59(5), 583-603. https://doi.org/10.1080/00313831.2014.965788

Hargreaves, A. (2007). Sustainable professional learning communities. In L. Stoll \& K. S. Louis (Eds.), Professional learning communities: Divergence, depth and dilemmas. McGraw-Hill Education (UK).

Hargreaves, A., \& Fink, D. (2006). Sustainable Leadership. San Francisco: Jossey-Bass.

Hargreaves, A., \& Fullan M. (2012). Professional Capital. Transforming Teaching in Every School. New York: Teachers College Press.

Harris, A. (2004). Distributed leadership and school improvement leading or misleading? Educational Management Administration \& Leadership, 32(1), 11-24. https://doi.org/ 10.1177/1741143204039297

Harris, A. (2008). Distributed leadership: According to the evidence. Journal of Educational Administration, 46(2), 172-188. https://doi.org/10.1108/09578230810863253

Harris, A. (2011). System improvement through collective capacity building. Journal of Educational 
Administration, 49(6), 624-636. https://doi.org/ 10.1108/09578231111174785

Heck, R. H., \& Hallinger, P. (2009). Assessing the contribution of distributed leadership to school improvement and growth in math achievement. American Educational Research Journal, 46(3), 659-689. https://doi.org/10.3102/0002831209340042

Hipp, K., Huffman J., Pankake, A., \& Olivier D. (2008). Sustaining professional learning communities: Case studies. Journal of Educational Change, 9, 173-195. https://doi.org/10.1007/s10833-007-9060-8

Hord, S. (1997). Professional Learning Communities: Communities of continuous Inquiry and Improvement. Southwest Educational Development Laboratory, Austin, TX. Retrieved from https://files.eric.ed.gov/fulltext/ED410659.pdf

Hord, S. M. (2008). Evolution of the professional learning community: Revolutionary concept is based on intentional collegial learning. Journal of Staff Development, 29(3), 10-13. Retrieved from https://search-proquest-com.libproxy.helsinki.fi/docview/211516745?accountid=11365

Hord, S. M. (2009). Professional learning communities. Journal of Staff Development, 30(1).

Hord, S. M. (Ed.). (2004). Learning together, leading together: Changing schools through professional learning communities. Teachers College Press.

Hord, S. M., Meehan, M. L., Orletsky, S., \& Sattes, B. (1999). Assessing a School Staff as a Community of Professional Learners. Issues... about Change, 7(1), n1. Retrieved from https://eric.ed.gov/?id=ED439490

Hord, S., \& Sommers W. A. (2008). Leading professional learning communities: Voices from research and practice. Thousand Oaks, CA: Corwin Press \& National Association of Secondary School Principals.

Huffman, J. B., \& Hipp, K. K. (2003). Reculturing schools as professional learning communities. Lanham. MD: Scarecrow Education.

Ilomäki, L., Lakkala, M., Toom, A., \& Muukkonen, H. (2017). Teacher Learning within a Multinational Project in an Upper Secondary School. Education Research International. http://doi.org/10.1155/2017/1614262

Jahnukainen, M. (2011). Different Strategies, Different Outcomes? The History and Trends of the Inclusive and Special Education in Alberta (Canada) and in Finland. Scandinavian Journal of Educational Research, 55(5), 489-502. https://doi.org/10.1080/00313831.2010.537689

Jensen, B., Sonnemann, J., Roberts-Hull, K., \& Hunter, A. (2016). Beyond PD: Teacher Professional Learning in High-Performing Systems. Teacher Quality Systems in Top Performing Countries. National Center on Education and the Economy. from http://www.ncee.org/wp-content/uploads/2015/08/BeyondPDWeb.pdf

Kennedy, A. (2014). Models of Continuing Professional Development: a framework for analysis. Professional Development in Education, 40(3), 336-351. http://dx.doi.org/10.1080/19415257.2014.929293

Kennedy, A., Deuel, A., Nelson, T. H., \& Slavit, D. (2011). Requiring collaboration or distributing leadership. Phi Delta Kappan, 92(8), 20-24. https://doi.org/10.1177/003172171109200805

Lakkala, M., \& Ilomäki, L. (2015). A cases study of developing ICT-based pedagogy through a collegial practice transfer process. Computers \& Education, 90, 1-12. http://dx.doi.org/10.1016/j.compedu.2015.09.001

Leana, C. (2011). The Missing Link in School Reform. Stanford Social Innovation Review. Leland Stanford Jr. University. Retrieved from https://ssir.org/articles/entry/the_missing_link_in_school_reform

Leclerc, M., Moreau, A. C., Dumouchel, C., \& Sallafranque-st Louis, IS. F. (2012). Factors that promote progression in schools functioning as professional learning community. International Journal of Education Policy \& Leadership, 7(7), 1-14. Retrieved from http://journals.sfu.ca/ijepl/index.php/ijepl/issue/view/66

Leithwood, K., \& Jantzi, D. (2000). Principal and teacher leadership effects: A replication. School Leadership \& Management, 20(4), 415-434. https://doi.org/10.1080/713696963

Leithwood, K., \& Mascall, B. (2008). Collective Leadership Effects on Student Achievement. Educational Administration Quarterly, 44. https://doi.org/10.1177/0013161X08321221

Leithwood, K., Mascall, B., Strauss, T., Sacks, R., Memon, N., \& Yashkina, A. (2007). Distributing leadership to make schools smarter: Taking the ego out of the system. Leadership \& Policy in Schools, 6(1), 37-67. https://doi.org/10.1080/15700760601091267

Little, J. W. (2012). Professional community and professional development in the learning-centered school. In M. 
Kooy \& K. van Veen (Eds.), Teacher learning that matters: International perspectives (pp. 22-43). New York: Routledge.

Lomos, C. (2017). To what extent do teachers in European countries differ in their professional community practices? School Effectiveness and School Improvement, 28(2), 276-291. https://doi.org/10.1080/09243453.2017.1279186

Lomos, C., Hofman, R. H., \& Bosker, R. J. (2011). Professional communities and student achievement: a meta-analysis. School Effectiveness and School Improvement, 22(2), 121-148. https://doi.org/10.1080/09243453.2010.550467

Louis, K. S., \& Kruse, S. D. (1995). Professionalism and community: Perspectives on reforming urban schools. SAGE.

Ministry of Education, Finland, MoE. (2001). Teacher education development programme.

Mitchell, C., \& Sackney, L. (2000). Profound improvement: Building capacity for a learning community. Lisse, The Netherlands: Swets \& Zeitlinger.

Morrissey, M. S. (2000). Professional learning communities: An ongoing exploration. Retrieved from http://www.willettsurvey.org/TMSTN/PLCs/plc-ongoing.pdf

Muñoz, M. A., \& Branham, K. E. (2016). Professional learning communities focusing on results and data-use to improve student learning: the right implementation matters. Planning and Changing, 47(1/2), 37.

Organization for Economic Co-operation and Development, OECD. (2012). Equity and Quality in Education: Supporting Disadvantaged Students and Schools. OECD Publishing. https://dx.doi.org/10.1787/9789264130852-en

Organization for Economic Co-operation and Development, OECD. (2015). Education at a Glance 2015: OECD Indicators. OECD Publishing. https://dx.doi.org/10.1787/eag-2015-en

Owen, S. (2015). Teacher professional learning communities in innovative contexts: 'ah hah moments'. 'passion' and 'making a difference' for student learning. Professional Development in Education, 41(1), 57-74. https://doi.org/10.1080/19415257.2013.869504

Pietarinen, J., Pyhältö, K., \& Soini, T. (2017). Large-scale curriculum reform in Finland-exploring the interrelation between implementation strategy, the function of the reform, and curriculum coherence. The Curriculum Journal, 28(1), 22-40. https://doi.org/ 10.1080/09585176.2016.1179205

Programme for International Student Assessment. (2007). PISA 2006: Science Competencies for Tomorrow's World (Volume 1, Analysis). OECD Publishing.

Pyhältö, K., Pietarinen, J., \& Soini, T (2012). Do comprehensive school teachers perceive themselves as active agents in school reforms? Journal of Educational Change, 13(1), 95-116. https://doi.org/10.1007/s10833-011-9171-0

Richmond, G., \& Manokore, V. (2011). Identifying elements critical for functional and sustainable professional learning communities. Science Education, 95(3), 543-570. https://doi.org/10.1002/sce.20430

Robinson, V. M., Hohepa, M., \& Lloyd, C. (2007). School leadership and student outcomes: Identifying what works and why, 41. Winmalee: Australian Council for Educational Leaders.

Sahlberg, P. (2011). Finnish Lessons. What can the world learn from educational change in Finland? New York: Teacher College Press.

Senge, P. M. (1996). Leading learning organizations. Training \& Development, 50(12), 36.

Sigurðardóttir, A. K. (2010). Professional Learning Community in Relation to School Effectiveness. Scandinavian Journal of Educational Research, 54(5), 395-412. https://doi.org/10.1080/00313831.2010.508904

Sleegers, P., den Brok, P., Verbiest, E., Moolenaar, N. M., \& Daly, A. J. (2013). Toward conceptual clarity. Elementary School Journal, 114(1), 118-137. https://doi.org/10.1086/671063

$\begin{array}{llll}\text { Statistics } & \text { Finland. (2018). } & \text { Retrieved }\end{array}$ http://www.stat.fi/til/kjarj/2017/kjarj_2017_2018-02-13_tie_001_fi.html

Stoll, L., Bolam R., \& Greenwood, A. (2007). Professional Learning Communities: Divergence, Detail, Difficulties. Open University Press. 
Stoll, L., Bolam, R., McMahon, A., Wallace, M., \& Thomas, S. (2006). Professional learning communities: a review of the literature. Journal of Educational Change, 7, 221-258. https://doi.org/10.1007/s10833-006-0001-8

Stoll, L., Bolam, R., McMahon, A., Wallace, M., \& Thomas, S. (2006). Professional learning communities: a review of the literature. Journal of Educational Change, 7(4), 1-38.

Teasley, M. L. (2017). Organizational culture and schools: A call for leadership and collaboration. Children and Schools, 39(1), 3-6. https://doi.org/10.1093/cs/cdw048

The Conference board of Canada. (2014). Education and skills. Retrieved from http://www.conferenceboard.ca/hcp/provincial/education.aspx

The Finnish Ministry of culture and education, FMEC. (2015). Tomorrows' comprehensive school. Publications 2015:8. Retrieved from http://urn.fi/URN:ISBN:978-952-263-340-8

The Finnish National Board of Education, FNBE. (2014). The national core curriculum.

The Finnish National Board of Education, FNBE. (2014). What is changing and why? Retrieved from http://www.oph.fi/download/155459_opetussuunnitelmasta_opettajille_mika_muuttuu_ja_miksi_25012014. pdf

The Finnish National Board of Education, FNBE. (2016). Teachers and principals in Finland 2016. Retrieved from http://www.oph.fi/download/185381_teachers_and_principals_in_Finland_2016_brochure.pdf

Tian, M., Risku, M., \& Collin, K. (2015). A meta-analysis of distributed leadership from 2002 to 2013 Theory development, empirical evidence and future research focus. Educational Management Administration \& Leadership, 44(1), 146-164. https://doi.org/10.1177/1741143214558576

Tschannen-Moran, M. (2004, November). What's trust got to do with it? The role of faculty and principal trust in fostering student achievement. In annual meeting of the University Council for Educational Administration, Kansas City, MO.

Van Houtte, M. (2005). Climate or Culture? A plea for conceptual clarity in school effectiveness research. School Effectiveness and School Improvement, 16(1), 71-89. https://doi.org/10.1080/09243450500113977

Vescio, V., Ross, D., \& Adams, A. (2008). A review of research on the impact of professional learning communities on teaching practice and student learning. Teaching and Teacher Education, 24(1), 80-91. https://doi.org/10.1016/j.tate.2007.01.004

Wahlstrom, K. L., \& Louis, K. S. (2008). How teachers experience principal leadership: The roles of professional community, trust, efficacy, and shared responsibility. Educational Administration Quarterly, 44(4), 458-495. https://doi.org/10.1177/0013161X08321502

Webb, R., Vulliamy, G., Sarja, A., Hamalainen, S., \& Poikonen, P. (2009). Professional learning communities and teacher well-being? A comparative analysis of primary schools in England and Finland. Oxford Review of Education, 35(3), 405-422. https://doi.org/10.1080/03054980902935008

Williams, R., Brien, K., \& LeBlanc, J. (2012). Transforming schools into learning organizations: supports and barriers to educational reform. Canadian Journal of Educational Administration and Policy, 134. Retrieved from https://journalhosting.ucalgary.ca/index.php/cjeap/article/view/42834/30691

Williams, R., Brien, K., Sprague, C., \& Sullivan, G. (2008). Professional Learning Communities: Developing a School-Level Readiness Instrument. Canadian Journal of Educational Administration and Policy, 74. Retrieved from https://files.eric.ed.gov/fulltext/EJ807003.pdf 
Appendix A. The statements, scales, clusters based on the analysis and means

\begin{tabular}{|c|c|c|c|c|}
\hline Statements & Cluster 1. & Cluster 2. & Cluster 3. & $M$ \\
\hline \multicolumn{5}{|l|}{ Culture } \\
\hline C1. This school has a culture of collegiality, trust, and commitment. & 4.6 & 4.3 & 3.9 & 4.3 \\
\hline C2. The culture in this school supports professional collaboration. & 4.3 & 4.2 & 3.9 & 4.1 \\
\hline $\begin{array}{l}\mathrm{C} 3 \text {. Teachers in this school have the time to collaborate with their colleagues } \\
\text { regarding student learning }\end{array}$ & 3.7 & 2.9 & 2.8 & 3.1 \\
\hline $\begin{array}{l}\text { C4. The impact that structural factors have on professional collaboration are } \\
\text { addressed in this school. }\end{array}$ & 3.3 & 3.3 & 2.7 & 3.1 \\
\hline C5. In this school we recognize the importance of effective communication. & 3.7 & 3.3 & 3.0 & 3.4 \\
\hline$M$ & 3.9 & 3.6 & 3.3 & 3.6 \\
\hline \multicolumn{5}{|l|}{ Leadership } \\
\hline $\begin{array}{l}\text { L1. School leadership in this school is grounded in effective organizational } \\
\text { practices. }\end{array}$ & 3.6 & 3.4 & 2.8 & 3.3 \\
\hline $\begin{array}{l}\text { L2. Building leadership capacity among both teachers and support staff } \\
\text { reinforces learning for both teachers and students in this school. }\end{array}$ & 4.0 & 3.9 & 3.3 & 3.8 \\
\hline L3. The sharing of leadership strengthens the leadership capacity of this school. & 4.3 & 3.7 & 3.5 & 3.8 \\
\hline $\begin{array}{l}\text { L4. Decisions in this school are based on careful analysis of school-based data } \\
\text { on student performance. }\end{array}$ & 3.3 & 3.1 & 2.7 & 3.0 \\
\hline $\begin{array}{l}\text { L5. Decisions regarding resource allocation are made by those most involved in } \\
\text { their use. }\end{array}$ & 3.9 & 3.3 & 3.0 & 3.4 \\
\hline$M$ & 3.8 & 3.5 & 3.1 & 3.5 \\
\hline \multicolumn{5}{|l|}{ Teaching } \\
\hline $\begin{array}{l}\text { T1. Teachers in this school are encouraged to use professional collaboration to } \\
\text { learn effective instructional and assessment practices. }\end{array}$ & 4.3 & 4.1 & 3.6 & 4.0 \\
\hline $\begin{array}{l}\text { T2. Instructional practices in this school meet the needs of students of all ability } \\
\text { levels. }\end{array}$ & 4.3 & 4.2 & 3.9 & 4.1 \\
\hline $\begin{array}{l}\text { T3. Effective lesson planning is vital for improving student achievement in our } \\
\text { school. }\end{array}$ & 3.4 & 3.2 & 2.9 & 3.2 \\
\hline $\begin{array}{l}\text { T4. In this school interventions are provided to students who require additional } \\
\text { support. }\end{array}$ & 4.3 & 4.4 & 4.1 & 4.3 \\
\hline $\begin{array}{l}\text { T5. In this school, assessment is a key component of instructional practices and } \\
\text { contributes to student learning. }\end{array}$ & 4.0 & 3.5 & 3.3 & 3.6 \\
\hline$M$ & 4.1 & 3.9 & 3.6 & 3.8 \\
\hline \multicolumn{5}{|l|}{ Professional growth and development } \\
\hline $\begin{array}{l}\text { PD1. In this school, professional growth is a multi-faceted. systemic and } \\
\text { on-going component of school improvement efforts }\end{array}$ & 4.2 & 4.1 & 3.6 & 3.9 \\
\hline PD2. Professional growth is supported in this school. & 3.7 & 3.2 & 2.9 & 3.3 \\
\hline $\begin{array}{l}\text { PD3. Our teachers have the knowledge skills and dispositions to engage in } \\
\text { professional collaboration. }\end{array}$ & 4.3 & 4.1 & 3.8 & 4.1 \\
\hline $\begin{array}{l}\text { PD4. Professional development for teachers is organized using a comprehensive } \\
\text { plan focusing on our school's vision. }\end{array}$ & 3.3 & 3.2 & 2.6 & 3.0 \\
\hline PD5. In this school, mentorship provides for professional growth. & 3.6 & 3.4 & 2.7 & 3.2 \\
\hline$M$ & 3.8 & 3.6 & 3.1 & 3.5 \\
\hline
\end{tabular}

Appendix B. The schools and their means in the scales

\begin{tabular}{lllll}
\hline School $(N)$ & Culture $M(S D)$ & Leadership $M(S D)$ & Teaching $M(S D)$ & $P D M(S D)$ \\
\hline School 1 $(\mathrm{N}=16)$ & $3.2(0.4)$ & $3.0(0.5)$ & $3.3(0.4)$ & $3.1(0.5)$ \\
School 2 $(\mathrm{N}=23)$ & $3.4(0.3)$ & $3.3(0.4)$ & $3.6(0.4)$ & $3.4(0.5)$ \\
School $3(\mathrm{~N}=14)$ & $3.4(0.5)$ & $3.0(0.7)$ & $3.3(0.7)$ & $3.1(0.9)$ \\
School $4(\mathrm{~N}=24)$ & $3.3(0.5)$ & $3.3(0.4)$ & $3.3(0.5)$ & $2.9(0.4)$ \\
School $5(\mathrm{~N}=15)$ & $4.0(0.6)$ & $3.8(0.7)$ & $3.9(0.6)$ & $3.8(0.8)$ \\
School $6(\mathrm{~N}=13)$ & $3.9(0.4)$ & $3.6(0.5)$ & $3.8(0.5)$ & $3.8(0.6)$ \\
School $7(\mathrm{~N}=20)$ & $3.8(0.3)$ & $3.5(0.4)$ & $3.6(0.3)$ & $3.8(0.4)$ \\
School $8(\mathrm{~N}=21)$ & $3.8(0.6)$ & $3.6(0.6)$ & $3.6(0.6)$ & $3.5(0.5)$ \\
School $9(\mathrm{~N}=15)$ & $3.2(0.4)$ & $3.0(0.5)$ & $3.2(0.4)$ & $3.2(0.5)$ \\
School 10 $(\mathrm{N}=11)$ & $3.9(0.4)$ & $3.9(0.4)$ & $4.0(0.5)$ & $4.0(0.4)$ \\
School 11 $(\mathrm{N}=13)$ & $3.6(0.5)$ & $3.4(0.6)$ & $3.9(0.5)$ & $3.7(0.6)$ \\
School 12 $(\mathrm{N}=11)$ & $3.3(0.7)$ & $2.9(0.7)$ & $3.6(0.6)$ & $3.3(0.6)$ \\
School 13 $(\mathrm{N}=16)$ & $3.5(0.4)$ & $3.6(0.5)$ & $3.6(0.3)$ & $3.6(0.5)$ \\
\hline Total & $3.6(0.5)$ & $3.4(0.6)$ & $3.6(0.5)$ & $3.5(0.6)$ \\
\end{tabular}




\section{Copyrights}

Copyright for this article is retained by the author(s), with first publication rights granted to the journal.

This is an open-access article distributed under the terms and conditions of the Creative Commons Attribution license (http://creativecommons.org/licenses/by/4.0/). 